\title{
A Value Centred Paradigm to Moderate the Digital Transformation of Manufacturing
}

\author{
Luzian Dold \\ Middlesex University, The Burroughs Hendon, London NW4 4BT, United Kingdom \\ *Corresponding author email: Luciandold@aol.com
}

Received: 22 February 2021 / Revised: 27 March 2021 / Accepted: 29 March 2021 / Published: 03 April 2021

\begin{abstract}
Digital transformation affects almost all areas of society and business and is of increasing interest to academics and industry practitioners. New digital technology is expected to enable manufacturing companies to capture competitive and productivity advantages compared to conventional methods. Aggregated information based on production process data represent a new production factor to generate innovative forms of digital value generation. Paradoxically, the implementation of digitalised production in manufacturing companies remains at unexpected low levels as companies' investment decisions often vote against digitalisation due to uncertainty in judging novel forms of criteria related to digital value. Digital transformation constates a new set of latent structure and relationships to generate, capture and monetise value. A holistic view on heterogenous research disciplines related with digital transformation of production is proposed in this short communication. This research presents a new paradigm which takes the moderation function of value propositions, value architectures and value capture to evaluate projects relative to digitalised manufacturing.
\end{abstract}

Keywords: Digitalised production, digital transformation, value capture, Industry 4.0, value architecture, value proposition

\section{Introduction}

The importance of digitalisation for strategic considerations increased significantly since the term "Industrie 4.0" was introduced to public back in 2011 (Kagermann et al. 2011). Wide ranging economic and productivity effects has been predicted by consultants, $\mathrm{PwC}$ for example estimated additional revenues of 110 billion $€$ and productivity gains of up to $18 \%$ in their study from 2014 (Geissbauer et al. 2014, p. 10f). In contrast, the research of Staufen.AG (2019, p. 10) shows $9 \%$ of manufacturing companies within the high technology segment like automotive and electronics did use digitalisation technology operative in the fashion of Industrie 4.0 in 2018. The same survey shows a share of $41 \%$ did not pay attention to operative use so far.

Digitalisation is widely discussed in society and the media; however, business strategies and manufacturing infrastructure appear to stay with traditional "analogue" paradigms. Research in the field of digitalised production is primarily concerned with technology aspects (Dorst 2015; Imtiaz and Jasperneite 2013). The criteria to evaluate investments and long-term impacts are usually not 'subjects of discussion' within research related to digitalisation /Industrie 4.0 (Veile et al. 2019). Complexity and uncertainty of digital investments compared to traditional analogue investments appear to be the cause for the hesitation to use strategic value generation from digitalised production. To ground a new view on the benefits available from digitalised production, a mixed methods research delivers insight into how value is moderating within the complex process of digital transformation. Section 2 describes the basics related to the research approach. In section 3 the applied research methodology is explained. Section 4 introduces the new value-based paradigm and the related evaluation model and tools. Section 5 concludes and proposes the adoption of a value centric view towards digital transformation of production. 


\section{Considerations of digitalised production}

In this section the theoretical underpinnings that relate with the digital transformation of manufacturing is outlined and discussed.

\subsection{Definition}

Shop floor data and information originating from machines, production systems and their respective sensors and control devices, are the basis for digitalised value creation in relation to industrial production. Horizontal data integration is based on sufficiently available data from the vertical data integration of discrete manufacturing steps within a production system. The consistent availability of the horizontal data stream based on vertical data in production build the technical requirements for Industrie 4.0 in manufacturing (Dorst 2015, p. 26). The capture of value from data originated within vertical integration is of essential interest and can be assessed economically as a new production factor beside resources, labour, and capital (Maier and Weber 2013, p. 9).

\subsection{Heterogenous theoretical base}

Literature sources do not cover the aspects of digital transformation as a holistic research field. Four major research disciplines form the state-or-the-art of available sources to deliver the necessary theoretical foundation of this research.

Publications related with digitalisation initiatives such as Industrie 4.0 (Kagermann et al. 2011), IVI (Industrial Value Chain Initiative 2018) or IIC (Lin et al. 2017) are concept-oriented and focus on required technology. Technology centric publications take advantage of new development trends such as OPC-UA (OPC Specification), MQT'T, big data or artificial intelligence as the core of research (Palm et al. 2014; Sauer 2014; Henssen and Schleipen 2014). Business models are examined from the perspective of corporate strategy and their specific domain, for example e-commerce or information technology. Business model research considers business issues with external partners, like B2B, B2C and the aspects related to the "office floor" (Osterwalder 2004; Rese et al. 2013; Chesbrough and Rosenbloom 2002). In the same fashion, the work resulting from research focus on manufacturing, is dedicated to investigative tools for continuous productivity increase on the "shop floor" (Ylipää et al. 2017; Schmenner 2015; Gibbons and Burgess 2010).

\subsection{Productivity, OEE and data value}

Productivity characterises the ability to achieve a continuous improvement of yield within given investment limitations (Schmenner 2015, p. 341). In the 20th century, improvements of productivity were determined by optimised mass production and subsequently were complemented by flexible production concepts such as Manufacturing Resource Planning (MRP) or Total Productive Management (TPM) (Hopp and Spearman 2004, p. 134). The implementation of these concepts is reflected in manufacturing optimisation methods such as Six Sigma, Lean Manufacturing, Total Equipment Effectiveness Performance, Production Equipment Effectiveness and many more. Muchiri and Pintelon (2008, p. 3533) argue that all these approaches in principle measure by using the Overall Equipment Efficiency (OEE) methodology. OEE describes the ratio between the theoretical maximum production capacity and the actual realised result. Ylipää et al. (2017, p. 131f) state in their study that a sample of 94 OEE data sets from industrial production results in an average OEE of $51.5 \%$. Based on this score, the study shows that the industry has the potential to almost double productivity using the existing manufacturing infrastructure in pursuit of the remaining 48.5\% OEE.

Parallel to the physical value chain, information technology shows the monetary value of data and aggregated information to realise measurable effects (Iansiti and Lakhani 2014). A value chain of data economy has been defined by Maier and Weber (2013, p. 15) through determination of data related monetary value based on their level of aggregation. This value chain mandates the necessity to provide technological infrastructure to utilise data as the fourth production factor. 


\subsection{Value mechanism of business models}

The concept of the business model has found its way into the vocabulary of scholars during the so-called dotcom boom. Zott et al. (2011, p. 1023) show a consistent increase in publications between 1995 and 2009, that continues to date with 458 listed articles in EBSCOhost in 2019. Business models are interpreted differently in literature and are placed in different contexts towards customer benefit and corporate strategy (Zott et al. 2011, p. 1035). Over time, the value perception of business models changes due to the influence of available technology as visualised in Figure 1. So far there is literature exploring the first three categories, their mechanisms and structure. Models for the application of digitalisation have so far hardly been published as this dynamic or phenomenon is still in its infancy. The moderation of value has been impressively researched by Chesbrough and Rosenbloom and show the connection between technology and business models. They define the business model as a "mediating construct between technology and economic value" (Chesbrough and Rosenbloom 2002, p. 532). Al-Debei and Avison (2010) created a comprehensive framework for business models in information technology to explain how business strategy and operational processes need to be intersected with business model elements.

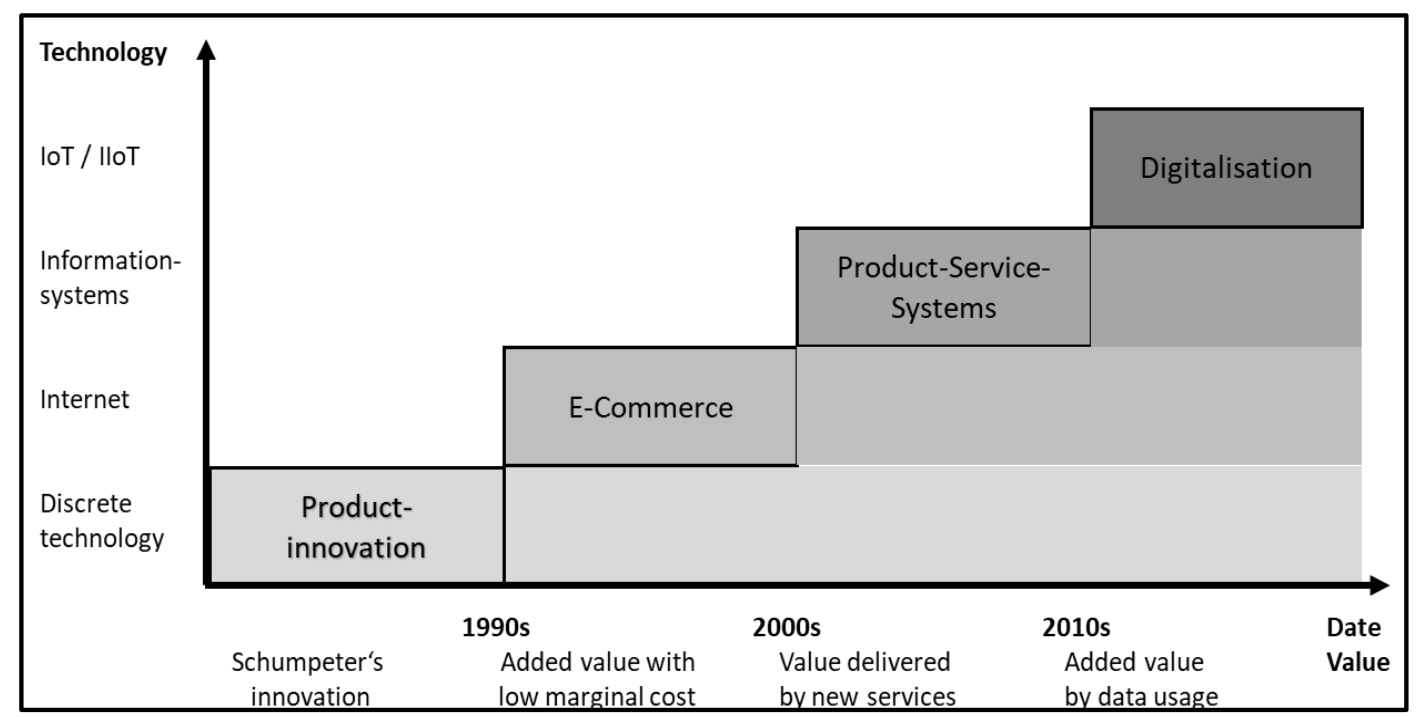

Figure 1: Evolution of business model and technology (Author's illustration)

The theory and scope of business models are heterogenous, however the central interest of value generation is common within the scholars analysed (Osterwalder 2004; Rese et al. 2013; Al-Debei and Avison 2010). In conclusion, business model research defines processes and interaction of related elements which focus on value proposition, value capture, value network and value architecture that are to be applied within digitalised manufacturing infrastructure.

\subsection{Digital gap}

Technological innovation has caused paradoxical situations already in the past. In the 1980's enterprises and the society entered the era of computerisation. Robert Solow stated in 1987 "You can see the computer age everywhere but in the productivity statistics" (Solow 1987). Since Solow's productivity paradox, we experienced the materialisation of values from computer usage and how additional benefits being generated with latency over time. Obermaier and Schweikl (2019, p. 540ff) researched the relevance of the Solow paradox in relation with manufacturing in an Industrie 4.0 environment. They demonstrated that several phenomena of the "fourth industrial revolution" appear to follow the same pattern as observed in the "computer revolution". The paradox of digitalised business has been summarised by Al-Debei and Avison (2010, p. 369) as a digital gap emerging from higher complexity and new levels of uncertainty. This does bias traditional business decisions towards a digital driven paradigm. Al-Debei and Avison propose to 
overcome such a digital gap using business models as a conceptual tool of "alignment" to bridge between corporate strategy and business processes (Al-Debei and Avison 2010, p. 371). Figure 2 explains how value elements are considered to intersect with the digital business strategy and the necessary digital business processes. The business model is understood as a "mediating construct between technology and economic value" (Chesbrough and Rosenbloom 2002, p. 532), therefore their value-oriented construction elements offer the way to reduce and bridge the identified digital gap to manage the paradoxical situation that complicates the use of digitalised technology in manufacturing.

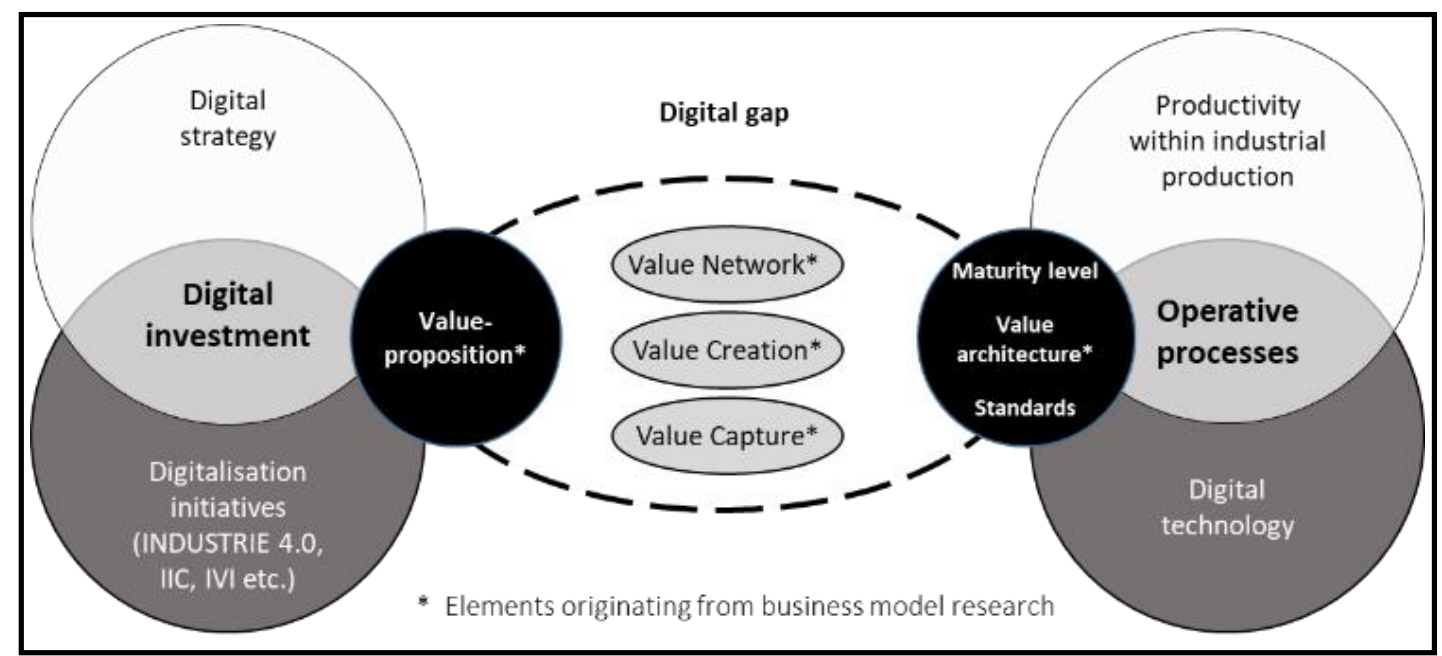

Figure 2: Value elements moderate the digital gap between strategy and operational process (Dold 2020, p.36)

\subsection{Summary}

The theoretical aspects related to digitalised production can only be covered with a wide range and combination of scientific disciplines. The central concern of manufacturing focus on productivity improvement based on OEE related indicators. Digital transformation adds complexity through novel interactions that generate added value by usage of digital technology and data. Analogue to recent technological transformations a paradoxical situation emerges from the underlaying uncertainties and initially insufficient digital maturity. Research related to the moderation of value within business models offer a promising solution to bridge the digital gap representing this situation. Based on this theoretical framework it is possible to define and perform a mixed method research delivering the insights to propose a new value-based paradigm.

\section{Research Methodology}

The incompatible focus of each research discipline does complicate a holistic research within the scope of digital transformation. The need to methodically combine the various aspects of research form a significant entry barrier to explore the process of digital transformation in manufacturing. Techno-economic interaction between digital transformation and conventional investment considerations must both be researched. A mixed-methods design is conducted to clarify to what extent decisions towards digital data integration in production are moderated by the utilisation of value elements originated from business model research.

Döring and Bortz (2016, p. 73) recommend the suitability of mixed methods, especially in application research, but critically point out possible scientific policy concerns. The advantages of a well-considered combination of methods to interface scientific disciplines in particular show many advantages. Javalgi et al. (2013, p. 164) demonstrate this by assessing research methods according to their suitability for theory development and theory testing instead the usual assessment following genuine research paradigms. Qualitative methods do develop the theoretical model and quantitative research confirms and explores the 
Luzian Dold, Adv. J Social Sci.; Vol. 8, Issue 1, pp: 86-95, 2021

empirical representation in the research. The qualitative study uses grounded theory (Charmaz 2014; Strauss and Corbin 2010) to determine relevant phenomena and their observable theoretical relationships. The quantitative evaluation is based on multivariate analysis methods including the structural equation model approach (Backhaus et al. 2016). The quantitative part of the mixed methods design tests the determinants originated from the grounded theory and allow further exploration and refinement of the results. Figure 3 compiles all steps within the chosen research design.

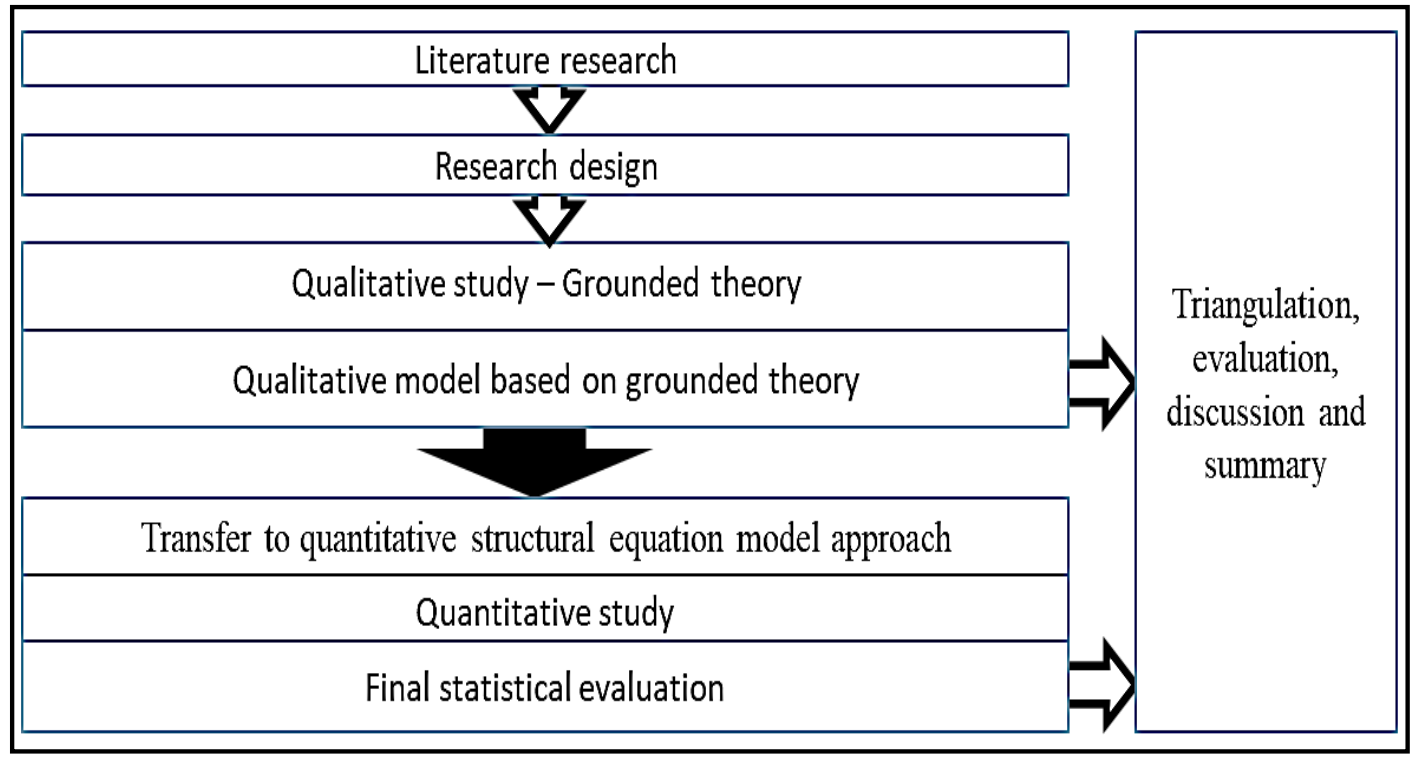

Figure 3: Mixed-methods research design (Author's illustration)

The research design is rich in applied methods and allow to triangulate research from different scientific disciplines. To achieve this combination, it is required to tolerate a pragmatic adoption of research paradigms. Researchers strictly following either quantitative or qualitative paradigms may argue this as weakness of the design on the one hand. For the given cross-disciplinary research questions on the other hand the application of various methods delivers deep insights and results outlined in the following section.

\section{$4 \quad$ Value based paradigm for digitalised production}

The path to capture the benefits offered by digitalised transformation in manufacturing is disturbed by its high complexity and associated new uncertainties (Magruk 2016). Traditional judgement criteria and investment metrics based on direct return on invest mark practical roadblocks to pursue digital innovation. The moderation function of value elements introduced in Section 2, mandates for a new value-based paradigm to evaluate and measure investments related to digitalised value generation. This section describes the applied mixed-methods research to understand how digital value generation is moderated. It summarises the results by explaining the grounded relations and relevant determinants. Finally, the innovative value-based toolset is proposed to support the new paradigm in company's practice.

\subsection{Determinants and relations}

The results of the mixed-methods study deliver wide ranging clarification. The qualitative grounded theory confirms the integrative function of value elements. Figure 4 visualises the Grounded-Theory-Model and demonstrates the role of value networks and value proposition as conditions to form the latent core category "associated balance". The value capture function is essential to determine the interaction resulting from the combination of the associated balance and the specific context (Dold 2020, p. 153f) . 
A Value Centred Paradigm to Moderate the Digital Transformation of Manufacturing

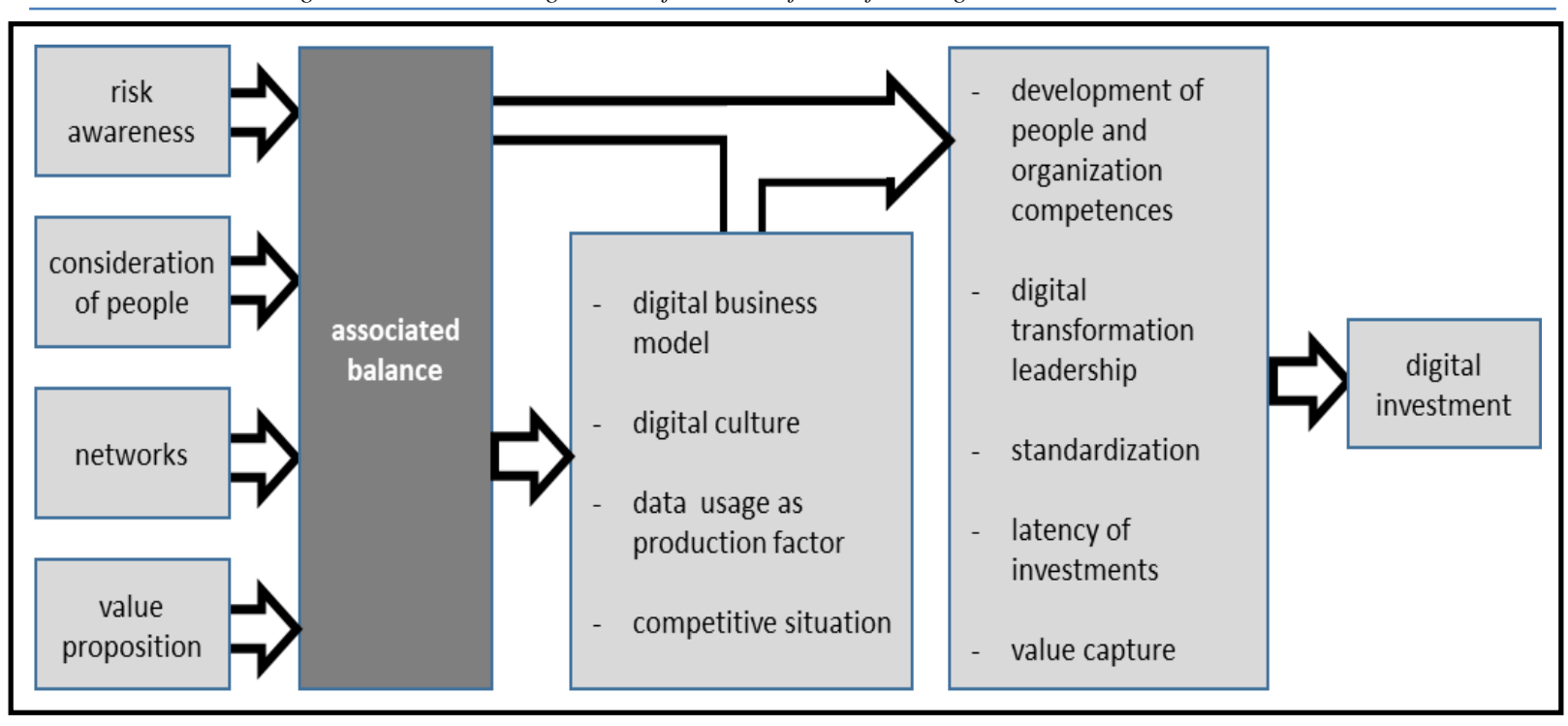

Figure 4: Grounded-Theory-Model (Dold 2020, p. 136)

Throughout the subsequent quantitative study, the moderating effects of value elements are confirmed and underline their moderation role within a value centric paradigm. The final model shows two latent exogenous constructs, digital maturity, and competitive situation. Two further latent endogenous constructs represent activities towards technology transformation and organisational transformation. These four latent constructs are measured by corresponding manifest variables as visualised in Figure 5. The value elements do bridge between the governing construct "digital maturity" and the corresponding transforming activities that determine investments towards technology and organisation. The definition of value proposition combined with the establishment of sustainable networks leads to the latent digital maturity level. The value creation function represents the significant moderating factor between digital maturity and the organisational respective the technological transformation alike. Considerations centred on value proposition, value networks and value creation support this new paradigm of decision taking towards the digitalised manufacturing technology as well the transformation of the related organisation.

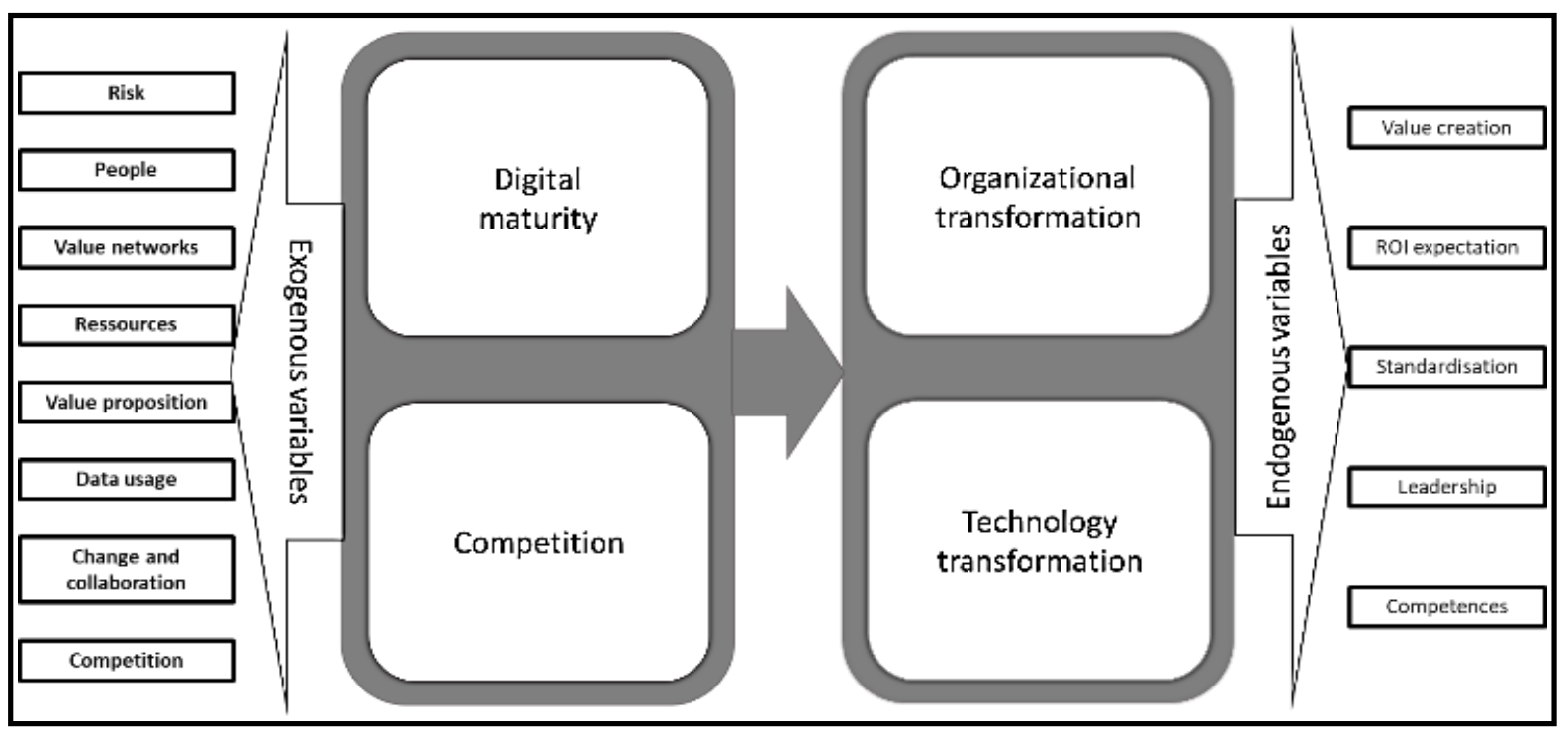

Figure 5: Alternative quantitative transformation model (Author's illustration) 
Luzian Dold, Adv. J Social Sci.; Vol. 8, Issue 1, pp: 86-95, 2021

\subsection{The value based toolset}

A value-based paradigm must be supported by tools based on transferred research results. The qualitative results deliver the building blocks to construct four guiding tools to assess and lead practitioners in the process of their digital projects. Figure 6 outlines the four tools within the toolbox. The Associated-BalanceCheck helps the operational team to judge their current capability to manage risks and deliver value from digital activities. The Context-Compass investigates the identified collateral elements and classifies the related context the project respectively the company does operate. This Context-Compass further considers how resources are available, data usage is applied, digital culture is pursued, and how far a digital business model exists. The Impact-Guide combines the results of the primary tools and utilises a comparison between the "as-is" situation and the desired "to-be" scenario by involving middle management stakeholders. To conclude the toolbox, the Investment-Validator connects senior management expectation and the previous evaluated patterns. The related gap analyse delivers recommendations to define corrective measures as well structure the digital value architecture for a successful value capture mechanism.

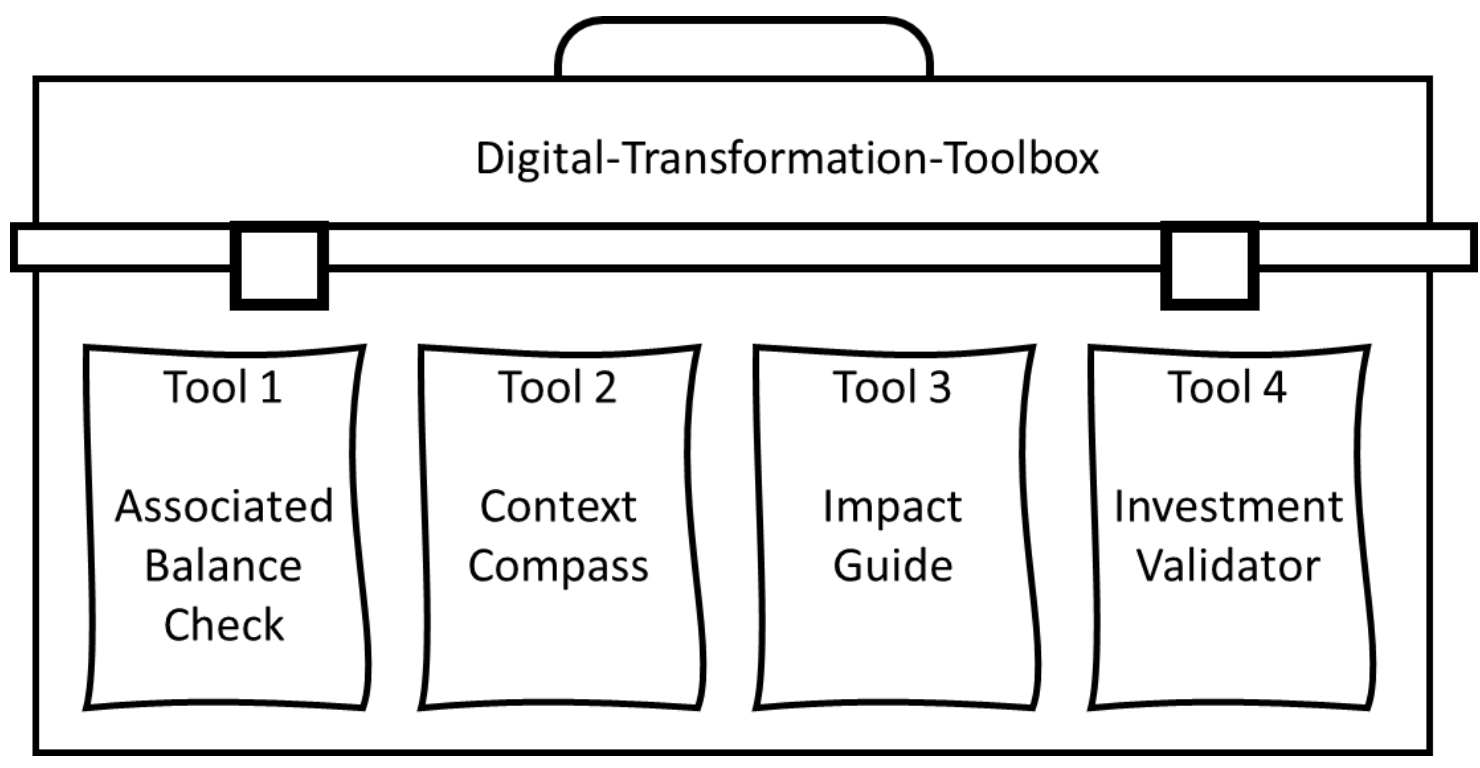

Figure 6: The Digital-Transformation-Toolbox (Author's illustration)

Further to the sequential nature of the Digital-Transformation-Toolbox, the quantitative study delivers a relational and holistic understanding on the moderation of value. Osterwalder and Pigneur created a manual to perform business model innovation. The core of this manual can be seen in the so-called "Business Model Canvas" (Osterwalder and Pigneur 2010, p. 12ff), summarising all the necessary building blocks for the development of business models in a clear structure. The Business Model Canvas is widespread used due to numerous scientific papers and is increasingly applied in companies to structure their strategy development processes. The practical workflow to structure digital transformation is similar in nature to the workflow of business model design. In addition, the central role of value is common for both approaches. As shown in figure 7, determinants of digital transformation can be clearly visualised in form of a canvas, taking the value capture as central element. The usage of a Digital-Transformation-Canvas offers powerful assistance for practical management of advanced digital transformation projects. 
A Value Centred Paradigm to Moderate the Digital Transformation of Manufacturing

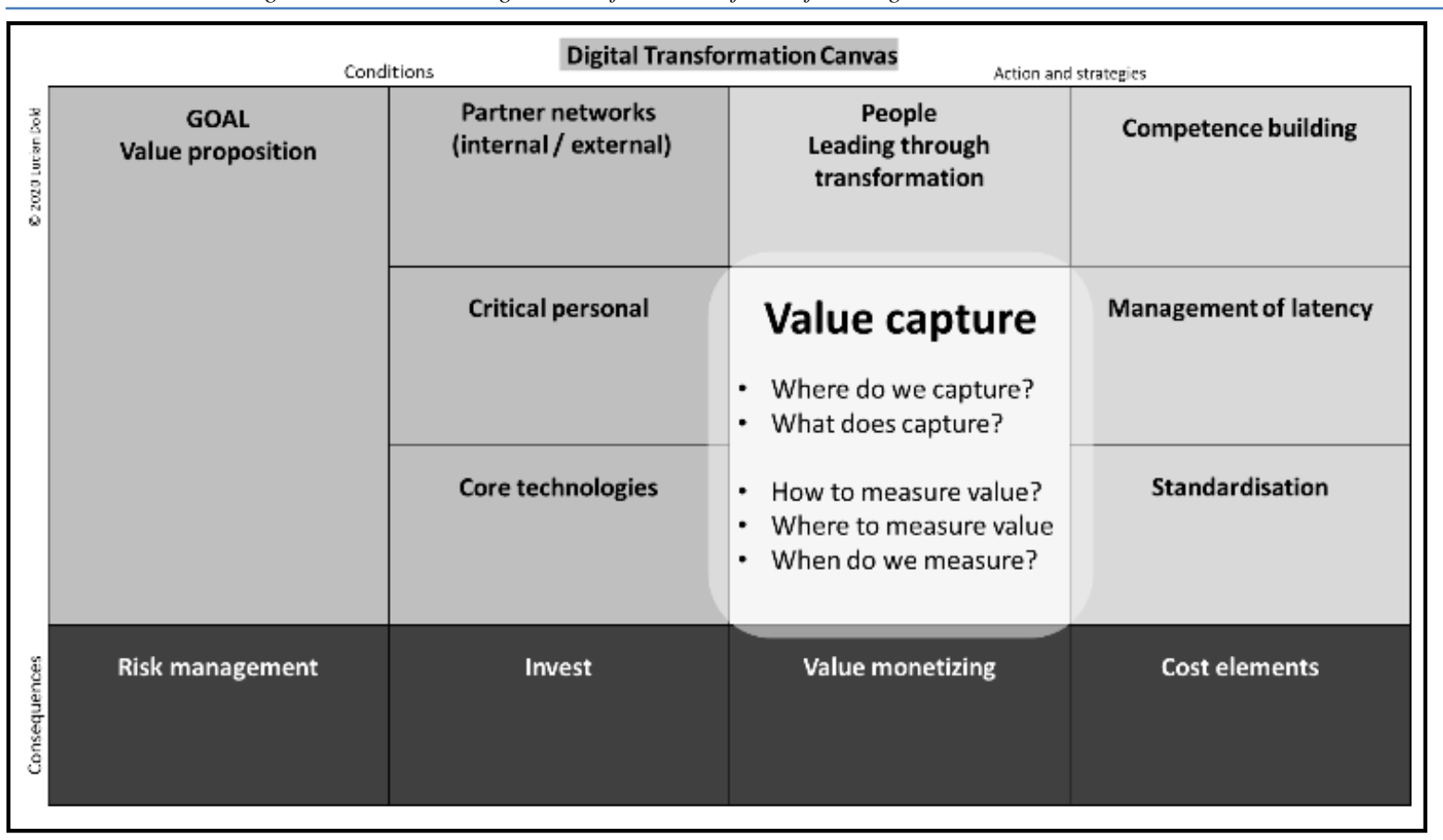

Figure 7: The Digital-Transformation-Canvas (Author's illustration)

\subsection{Summary}

The mixed-methods study delivers qualified results to identify interrelations between the complex set of determinants within the digital transformation of production. It can be constated, that the aggregated level of digital maturity is the key factor to influence decisions towards actions and investments into digitalised infrastructure. The practical situation of companies based on the given digital maturity will recommend the suitability of the available tools. For pragmatic use of the value-based paradigm the sequential process toolbox based on the underlying grounded-theory-model can be easily applied. In considerations following a conceptional and holistic process, the Digital-Transformation-Canvas offers a method to apply the transferred results grounded on empirical research. Transfer of results in the described value-based tools promises benefits for the practical usage. At the same time implications need to be considered as complexity remains a barrier. The concept of value constructs and related value creation process requires a critical review of proven thought processes. Missing to embrace the value centric nature of the proposed tools may deliver insufficient practical results.

\section{Conclusion}

The digital transformation of conventional production promises a new dimension of digital value generation. Innovative digitalised technology carries potential to really revolutionise existing manufacturing paradigms with new magnitudes of productivity improvement, quality, resilience, and flexibility. Likewise, to the experience made with the Solow paradox on computerisation, openness to adjust traditional processes and structures are important pre-conditions to benefit from digitalised technology in manufacturing. The research addresses the problem to combine existing state-of-the-art scientific disciplines that influence the judgement of digitalised investments but do not show methodical compatibility. The sophisticated mixed-methods research design delivered insights on the structural interrelations of digital value generation in manufacturing. It surfaces the latent constructs within the system of variables to understand the moderating function of value-based elements. The most important finding is composed by the importance of generation and capturing of digital value. Consequently, a value-based paradigm to evaluate and pursue digital transformation has been developed and transferred into relevant practical tools. The Digital-Transformation-Toolbox offers a process-oriented guidance to increase the 
Luzian Dold, Adv. J Social Sci.; Vol. 8, Issue 1, pp: 86-95, 2021

digital maturity and reduce the usual uncertainties especially at the beginning of the digital transformation journey. The holistic and conceptual Digital-Transformation-Canvas offers practitioners with advanced digital maturity level a full value centric guidance. Beside the direct benefits from these findings and applied tools, the value-based paradigm nurtures an in depth understanding of the value creation mechanisms within the digital transformation. The further the digital maturity rises; the further value capture opportunities will be identified and monetised. Digitization is not an end in itself; digitization is the means to create new digital value, sustained by the value-based paradigm.

\section{Declarations}

\subsection{Study Limitations}

The study researched mainly the German industry sector for their investment behaviour. Depending on the different levels of digital maturity the results can't be easily generalised.

\subsection{Competing Interests}

The author declared that this study has not been ordered, financed and there is no conflict of interest.

\section{How to Cite this Article}

Dold, L. (2021). A Value Centred Paradigm to Moderate the Digital Transformation of Manufacturing. Advanced Journal of Social Science, 8(1), 86-95. Retrieved from https://journals.aijr.org/index.php/ajss/article/view/3563

\section{References}

Al-Debei, Mutaz M.; Avison, David (2010): Developing a unified framework of the business model concept. In European Journal of Information Systems 19 (3), pp. 359-376. DOI: 10.1057/ejis.2010.21.

Backhaus, Klaus; Erichson, Bernd; Plinke, Wulff; Weiber, Rolf (2016): Multivariate Analysemethoden. Eine anwendungsorientierte Einführung. 14., überarbeitete und aktualisierte Auflage. Berlin, Heidelberg: Springer Gabler.

Charmaz, Kathy (2014): Constructing grounded theory. 2nd edition. Los Angeles, London, New Delhi, Singapore, Washington DC: SAGE.

Chesbrough, Henry; Rosenbloom, Richard S. (2002): The role of the business model in capturing value from innovation: evidence from Xerox Corporation's technology spin-off companies. In Industrial and corporate change 11 (3), pp. 529-555. DOI: 10.1093/icc/11.3.529.

Dold, Luzian (2020): Beurteilung von Investitionen in die digitalisierte Produktion. Eine Mixed-Method-Studie zur moderierenden Wirkung von Nutzenkonstrukten aus Geschäftsmodellen an der Lücke zwischen digitaler Strategie und operativen Prozessen. Dissertation. Middlesex University, London

Döring, Nicola; Bortz, Jürgen (2016): Forschungsmethoden und Evaluation in den Sozial- und Humanwissenschaften. With assistance of Sandra Pöschl. 5. vollständig überarbeitete, aktualisierte und erweiterte Auflage. Berlin, Heidelberg: Springer.

Dorst, Wolfgang (2015): Umsetzungsstrategie Industrie 4.0. Ergebnisbericht der Plattform Industrie 4.0. With assistance of W. Dorst, C. Glohr, T. Hahn, U. Loewen, Rosen, R. Schiemann, T., F. Vollmar et al. Edited by BITKOM e.V., VDMA e.V., ZVEI e.V. Berlin, Frankfurt am Main.

Geissbauer, Reinhard; Schrauf Stefan; Koch Volkmar; Kuge Simon (2014): Industry 4.0 : Opportunities and Challenges of the Industrial Internet. Edited by Pricewaterhousecooper Aktiengesellschaft. München.

Gibbons, Paul M.; Burgess, Stuart C. (2010): Introducing OEE as a measure of lean Six Sigma capability. In Lean Six Sigma Journal 1 (2), pp. 134-156. DOI: 10.1108/20401461011049511.

Henssen, Robert; Schleipen, Miriam (2014): Interoperability between OPC UA and AutomationML. In Procedia CIRP 25, pp. 297-304. DOI: 10.1016/j.procir.2014.10.042.

Hopp, Wallace J.; Spearman, Mark L. (2004): To Pull or Not to Pull. What Is the Question? In Manufacturing \& Service Operations Management 6 (2), pp. 133-148. DOI: 10.1287/msom.1030.0028.

Iansiti, Marco; Lakhani, Karim R. (2014): Digital ubiquity: How connections, sensors, and data are revolutionizing business. In Harvard business review 92 (11), pp. 90-99.

Imtiaz, Jahanzaib; Jasperneite, Jürgen (2013): Scalability of OPC-UA down to the chip level enables "Internet of Things". In IEEE intelligent Systems, pp. 500-505. DOI: 10.1109/INDIN.2013.6622935.

Industrial Value Chain Initiative (2018): Industrial Value Chain Reference Architecture -Next. Strategic implementation framework of industrial value chain for connected industries. Edited by Industrial Value Chain Initiative. Monozukuri Nippon Conference c/o. Tokyo.

Javalgi, Rajshekhar G.; Granot, Elad; Alejandro, Thomas G. Brashear (2013): Qualitative Methods in International Sales Research. CrossCultural Considerations. In Journal of Personal Selling \& Sales Management 31 (2), pp. 157-170. DOI: 10.2753/PSS08853134310204.

Kagermann, Henning; Wahlster, Wolfgang; Lukas, Wolf-Dieter (2011): Industrie 4.0: Mit dem Internet der Dinge auf dem Weg zur 4. Industriellen Revolution. In VDI Nachrichten 2011, 4/1/2011 (13).

Lin, Shi-Wan; Crawford, Mark; Mellor, Stephen (2017): The Industrial Internet of Things Volume G1: Reference Architecture. Version 1.80. Needham, MA. In Industrial Internet Consortium (IIC) Tech. Rep. 
Magruk, Andrzej (2016): Uncertainty in the Sphere of the Industry 4.0 - Potential Areas to Research. In Business, Management \& Education/Verslas, Vadyba ir Studijos 14 (2), pp. 275-291. DOI: 10.3846/bme.2016.332.

Maier, W.; Weber, M. (2013): Management von Big-Data-Projekten. Leitfaden. Berlin: Bundesverband Informationswirtschaft,Telekommunikation und neue Medien e. V.

Muchiri, P.; Pintelon, L. (2008): Performance measurement using overall equipment effectiveness (OEE). Literature review and practical application discussion. In International Journal of Production Research 46 (13), pp. 3517-3535. DOI: 10.1080/00207540601142645.

Obermaier, Robert; Schweikl, Stefan (2019): Zur Bedeutung von Solows Paradoxon. Empirische Evidenz und ihre Übertragbarkeit auf Digitalisierungsinvestitionen in einer Industrie 4.0. In Robert Obermaier (Ed.): Handbuch Industrie 4.0 und Digitale Transformation. Betriebswirtschaftliche, technische und rechtliche Herausforderungen. 1st ed. 2019. Wiesbaden: Springer Fachmedien Wiesbaden, pp. 529-564.

OPC Specification, 2015: OPC Unified Architecture, Part1 - Overview and Concepts, Revision 1.03. Available online at www.opcfoundation.org,

Osterwalder, Alexander (2004): The business model ontology: A proposition in a design science approach. Dissertiation. Universite de Lausanne, Lausanne. Ecole des Hautes Etudes Commerciales.

Osterwalder, Alexander; Pigneur, Yves (2010): Business model generation: a handbook for visionaries, game changers, and challengers. Hoboken: John Wiley \& Sons.

Palm, Florian; Grüner, Sten; Pfrommer, Julius; Graube, Markus; Urbas, Leon (2014): open62541-der offene OPC UA Stack. In Onlinepublikation des Fraunhofer IOSB, Lehrstuhl Prozessleittechnik der RWTH Aachen; TU Dresden.

Rese, Mario; Meier, Horst; Gesing, Judith; Boßlau, Mario (2013): An ontology of business models for industrial product-service systems. In Yoshiki Shimomura, Koji Kimita (Eds.): The Philosopher's Stone for Sustainability. Proceedings of the 4th CIRP International Conference on Industrial Product-Service Systems, Tokyo, Japan, November 8th - 9th, 2012. Heidelberg: Springer (Lecture Notes in Production Engineering), pp. 191-196.

Sauer, Olaf (2014): Information Technology for the Factory of the Future - State of the Art and Need for Action. In Procedia CIRP 25, pp. 293-296. DOI: 10.1016/j.procir.2014.10.041.

Schmenner, Roger W. (2015): The Pursuit of Productivity. In Production and Operations Management 24 (2), pp. 341-350. DOI: 10.1111/poms.12230.

Solow, R. M. (1987): We'd better watch out. In New York Times Book Review 36.

Staufen.AG (2019): DEUTSCHER INDUSTRIE 4.0 INDEX 2018. Eine Studie der Staufen AG und der Staufen Digital Neonex GmbH. Köngen: Staufen AG.

Strauss, Anselm; Corbin, Juliet (2010): Grounded theory. Grundlagen qualitativer Sozialforschung. Unveränd. Nachdr. der letzten Aufl. Weinheim: Beltz.

Veile, Johannes; Kiel, Daniel; Voight, Kai-Ingo; Müller, Julian Marius (2019): Lessons learned from Industry 4.0 implementation in the German manufacturing industry. In Journal of Manufacturing Technology Management (ahead-of-print). DOI: 10.1108/JMTM-082018-0270.

Ylipää, Torbjörn; Skoogh, Anders; Bokrantz, Jon; Gopalakrishnan, Maheshwaran (2017): Identification of maintenance improvement potential using OEE assessment. In International Journal of Productivity and Performance Management 66 (1), pp. 126-143. DOI: 10.1108/IJPPM-01-2016-0028.

Zott, Christoph; Amit, Raphael; Massa, Lorenzo (2011): The Business model: Recent Developments and Future Research. In Journal of management 37 (4), pp. 1019-1042. DOI: 10.1177/0149206311406265.

Publish your research article in AIJR journals-

$\checkmark$ Online Submission and Tracking

$\checkmark$ Peer-Reviewed

$\checkmark \quad$ Rapid decision

$\checkmark \quad$ Immediate Publication after acceptance

$\checkmark$ Articles freely available online

$\checkmark \quad$ Retain full copyright of your article.

Submit your article at journals.aijr.org
Publish your books with AIJR publisher-

$\checkmark$ Publish with ISBN and DOI.

$\checkmark$ Publish Thesis/Dissertation as Monograph.

$\checkmark$ Publish Book Monograph.

$\checkmark \quad$ Publish Edited Volume/ Book.

$\checkmark$ Publish Conference Proceedings

$\checkmark \quad$ Retain full copyright of your books.

Submit your manuscript at books.aijr.org 